\section{Metabolism of Acid Mucopolysaccharides of the Rabbit's Dermis following Skin Treatment with Irritating Substances}

IN the rabbit's skin chronically treated with croton oil a remarkable change is observed in the ratio between hyaluronic acid and chondroitin sulphuric acid, the former largely prevailing over the latter after one month's treatment; the same change occurs when the skin is treated with carcinogenic substances ${ }^{1}$. These data supplement what is already known about the presence of mucopolysaccharides in inflammatory processes (see, for references up to 1959 , Delaunay and Bazin ${ }^{2}$ and, more recently, Borenson and Dalferes ${ }^{3}$, White et al. ${ }^{4}$, Zonta et al. ${ }^{5}$ ). So far as we know, no data are available concerning: the changes induced in the metabolism of mucopolysaccharides by those stimuli which elicit inflammation. The present work was concerned with the dynamics of the metabolism of acid mucopolysaccharides of the rabbit's skin treated for short periods of time with croton oil, evaluating the incorporation into them of glucose (as glucosamine and galactosamine).

Albino rabbits weighing $2 \cdot 5-3 \mathrm{~kg}$ were shaved on approximately $300 \mathrm{~cm}^{2}$ of the back. Half this surface was
Table 1 shows the treatments performed on each single animal and the specific activity of total hexosamines as well as that of glucosamine and galactosamine taken separately. These values were obtained from MPS extracted and hydrolysed separately from both control and treated areas of each animal's skin.

From examination of Table 1 it appears that:

(1) The activity of hexosamines obtained by hydrolysis of MPS extracted from the treated area is always stronger than that of corresponding hexosamines extracted from the control area.

(2) Such increase in activity occurs rapidly; it is, in fact, fairly evident in animals which were killed $3 \mathrm{~h}$ after the one treatment received.

(3) The increase in activity of glucosamine from MPS of the treated area (compared to that of the corresponding control area) is more relevant than the increase in activity of galactosamine from MPS of the treated area (still compared to that of the corresponding control area). The only exception is animal No. 1 , in which the treatment was notably weaker than the average.

The results of the present work suggest that under a local irritating stimulus there is an accelerated synthesis of acid mucopolysaccharides of the dermis, and that this

Table 1

\begin{tabular}{|c|c|c|c|c|c|c|c|}
\hline $\begin{array}{c}\text { Rabbit } \\
\text { No. }\end{array}$ & $\begin{array}{c}\text { No. treatments } \\
\text { with croton } \\
\text { oil }\end{array}$ & $\begin{array}{l}\text { Time of glucose } \\
\text { injection (h after } \\
\text { last treatment } \\
\text { with croton oil) }\end{array}$ & $\begin{array}{l}\text { Time of killing } \\
\text { (h after glucose } \\
\text { injection) }\end{array}$ & $\begin{array}{c}\text { Ratio between } \\
\text { activity of } \\
\text { hexosamines } \mathrm{T} \\
\text { and hexosamines } \mathrm{C}\end{array}$ & $\begin{array}{c}\text { Activity of } \\
\text { glucosamine } \\
\text { (c.p.m./mg) }\end{array}$ & $\begin{array}{c}\text { Activity of } \\
\text { galactosamine } \\
\text { (c.p.m./mg) }\end{array}$ & $\begin{array}{l}\text { Ratio between } \\
\text { activity of glucos- } \\
\text { amine and activity } \\
\text { of galactosamine }\end{array}$ \\
\hline $1^{*}$ & 2 , at $24 \mathrm{~h}$ & 0.5 & 18 & $2 \cdot 85$ & C $\quad 55.8$ & 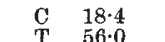 & $\begin{array}{cc}\mathrm{C} & 3.04 \\
\mathrm{~T} & 2.88\end{array}$ \\
\hline $2^{*}$ & 2 , at $70 \mathrm{~h}$ & 0.5 & 18 & $5 \cdot 3$ & $\begin{array}{r}101.0 \\
\mathrm{C} \quad 67.0\end{array}$ & C $\quad 26.0$ & C 2.6 \\
\hline 3 & $\underset{1}{\operatorname{distance}}$ & 6 & 18 & $11 \cdot 5$ & $\begin{array}{rr}\mathrm{T} & 282.0 \\
\mathrm{C} & 81.0\end{array}$ & $\begin{array}{ll}\mathrm{T} & 87 \cdot 5 \\
\mathrm{C} & 32.0\end{array}$ & $\begin{array}{ll}\mathrm{T} & 3.23 \\
\mathrm{C} & 2.55\end{array}$ \\
\hline 4 & 1 & 10 & 18 & $A$ & T 950.0 & $\begin{array}{r}116.0 \\
\mathrm{C}\end{array}$ & $\begin{array}{ll}\text { T } & 8 \cdot 2 \\
\text { C } & 3 \cdot 15\end{array}$ \\
\hline 4 & 1 & 10 & 18 & $6 \cdot 9$ & $\begin{array}{r}030 \\
\mathrm{~T}\end{array} 750.0$ & $\begin{array}{l}200 \\
\mathrm{~T} \quad 94.0\end{array}$ & T 8.0 \\
\hline $5 \dagger$ & 1 & 1 & 2 & $4 \cdot 13$ & $\mathrm{C} \quad 84 \cdot 0$ & $\begin{array}{l}23 \cdot 0 \\
51 \cdot 0\end{array}$ & $\begin{array}{ll}\overline{\mathbf{C}} & 3 \cdot 6 \\
& 7 \cdot 3\end{array}$ \\
\hline $6 \dagger$ & 1 & 1 & 2 & $4 \cdot 06$ & 86.0 & $25 \cdot 0$ & C 3.4 \\
\hline $7 \ddagger$ & 2 , at $24 \mathrm{~h}$ & 0.5 & 18 & $4 \cdot 3$ & $\begin{array}{rr}355 \cdot 0 \\
\mathrm{C}\end{array}$ & $\begin{array}{r}49 \cdot 0 \\
8 \cdot 0\end{array}$ & $\begin{array}{ll}T & 7 \cdot 2 \\
\mathrm{C} & 2 \cdot 7\end{array}$ \\
\hline & distance & & & & T $\quad 96.0$ & T $\quad 24 \cdot 0$ & $\begin{array}{ll}\mathrm{T} & \mathbf{4} \cdot 0 \\
\mathbf{C} & 0\end{array}$ \\
\hline 8 & $\begin{array}{l}2 \text {, at } 18 \mathrm{~h} \\
\text { distance }\end{array}$ & 0.5 & 18 & $3 \cdot 8$ & $\begin{array}{rr}\mathbf{C} & \mathbf{5 2 \cdot 0} \\
\mathbf{T} & 190 \cdot 0\end{array}$ & $\begin{array}{ll}\mathrm{C} & 24 \cdot 5 \\
\mathrm{~T} & 62 \cdot 0\end{array}$ & $\begin{array}{ll}\mathrm{C} & 2.12 \\
\mathrm{~T} & 3.05\end{array}$ \\
\hline
\end{tabular}

C, MPS extracted from the control area.

T, MPS extracted from the skin area treated with croton oil.

*'The amount of croton oil solution administered each time was notably inferior to the average. Also the macroscopic reaction, especially in the first animal, was less severe.

$\dagger$ Injected with $50 \mu \mathrm{c} . / \mathrm{kg}$, instead of $10 \mu \mathrm{c} . / \mathrm{kg}$.

t The anount of croton oil solution was larger than that normally used. The macroscopic reaction was quite evident, with a most marked cedema of both dermis and subcutaneous tissue. The activity of hexosamines of the control area is much less than average; probably the very strong treatment caused more than merely local effects.

treated, the other half was kept as control. Treatment was carried out with a 2.5 per cent solution of croton oil in acetone, dropped on the skin (about $1.5 \mathrm{ml}$. solution per $100 \mathrm{~cm}^{2}$ surface). Each animal was intravenously injected with $10 \mu \mathrm{c} . / \mathrm{kg}$ of glucose ${ }^{14} \mathrm{C}(\mathrm{U})$ (specific activity 3.57 mc./mmole) - except two which, as will be explained, received $50 \mu \mathrm{c} . \mathrm{kg}$. The times of injection and killing are reported in Table 1. The skin was removed separately from treated and control areas, leaving between the two areas a strip about $2 \mathrm{~cm}$ wide. The subcutaneous tissue was mechanically removed. The skins were minced and soaked in acetone, which was replaced three times in a week. The material was then dried, and acid mucopolysaccharides (MPS) were extracted from it after digestion with papain, by the method described by Scott ${ }^{6}$. Part of the MPS extracted was hydrolysed with $5 \mathrm{~N} \mathrm{HCl}$ for $7 \mathrm{~h}$ at $100^{\circ} \mathrm{C}$, and the hydrolysate was dried. Column chromatography $(0.8 \times 45 \mathrm{~cm})$ on 'Dowex $50 \mathrm{WX8}$ ', 200-400 mesh, was performed for the separation of glucosamine and galactosamine, according to Gardell?. Fractions of $3 \mathrm{ml}$. were collected. One ml. of each was used to determine the amount of hexosamine while the remaining $2 \mathrm{ml}$. were dried, and the material-recovered three times with distilled water-was placed on aluminium disks. Activity was assessed with a windowless gas-flow counter, with anti-coincidence scintillation apparatus (AlberigiQuaranta et al. $\left.{ }^{8}\right)$. response of the connective tissue occurs rapidly. Moreover, of the two predominant MPS of the skin, one (hyaluronic acid) contains glucosamine and the other (chondroitin sulphuric acid, especially of B type) contains galactosamine, so that one can safely conclude that the highest increase is found in the synthesis of hyaluronic acid. The inflammatory stimulus, therefore, develops its action not only by promoting an accelerated synthesis of MPS in fibroblasts, but also by directing it chiefly towards the production of hyaluronic acid. This fact may be at least partly responsible for the reported finding ${ }^{1}$ concerning the change in relationship between the two MPS, observed after one month's treatmont with either irritants or carcinogenic polycyclic hydrocarbons.

Institute of General Pathology,

G. Prodi University of Bologna,

Via S. Giacomo 14, Bologna, Italy.

1 Prodi, G., Brit. J. Cancer, 17, 504 (1963).

${ }^{2}$ Delaunay, A., and Bazin, S., Bull. Assoc. Diplomés de Microbiologie de la Faculté de Pharmacie de Nancy, 15 (1959)

3 Berenson, G. S., and Dalferes, E. R., Brit. J. Exp. Path., 41, 422 (1960).

- White, B. N.. Shetlar, M. R., and Schilling, J. A., Ann. N.Y. Acad. Sci.. 94, 297 (1961).

${ }^{5}$ Zonta, A., Ugazio, G., and Campani, M., Biochimica e Biologia Sperimentale, $2,63(1962)$.

O Scott, J F, Meth, Biochem. Analysis, 8, 145 (1960).

"Gardell, S., Acta Chem. Scand., " , 207 (1953).

${ }^{8}$ Alberigi-Quaranta, A., Righini, B., Prodi, V., and Rimondi, O., Nuclear Instruments and Methods, 14, 13 (1961). 